\title{
PEMANFAATAN ABU SEKAM PADI UNTUK PEMURNIAN BAHAN BAKU DAN PRODUK BIODIESEL DARI MINYAK JELANTAH
}

\author{
${ }^{1}$ R.B. Istiningrum, ${ }^{2}$ Priyadi, E.A, ${ }^{3}$ Sulfiah, L.A., ${ }^{4}$ Nafisah, D \\ 1234 Prodi DIII Analis Kimia Fakultas MIPA \\ Universitas Islam Indonesia \\ Yogyakarta, Indonesia \\ Email: reni_banowati@uii.ac.id
}

\begin{abstract}
Abstrak
Abu sekam padi (ASP) merupakan limbah pada proses pembakaran batu bata yang berpotensi sebagai adsorben karena memiliki kandungan silika yang tinggi. Penelitian ini bertujuan untuk mengetahui potensi abu sekam padi sebagai adosorben pada proses pembuatan biodiesel dari minyak jelantah. Abu sekam padi diaplikasikan dalam pemurnian minyak jelantah dan juga produk biodiesel. Penelitian ini dilakukan dengan beberapa tahap yaitu karakterisasi ASP, pemurnian minyak jelantah, pembuatan biodiesel melalui transesterifikasi dengan katalis $\mathrm{NaOH}$, pemurnian biodiesel dengan ASP 1, 3, 5\% serta karakterisasi biodiesel. Abu sekam padi memiliki luas area spesifik dengan metode metilen biru sebesar 119,59 $\mathrm{m}^{2} / \mathrm{g}$. Abu sekam padi dapat menurunkan kadar asam lemak bebas dalam minyak jelantah sebesar $62,4 \%$. Proses transesterifikasi minyak jelantah menghasilkan biodiesel sebesar $96 \%$. Masa ASP optimum untuk memurnikan biodiesel adalah $3 \%$ dengan nilai bilangan asam, gliserol total dan bilangan ester berturut-turut adalah $2,5 \mathrm{mg} \mathrm{KOH} / \mathrm{g}, 0,37 \%$ dan $98,37 \%$. Kualitas biodiesel yang dihasilkan belum memenuhi persyaratan SNI.
\end{abstract}

Kata kunci: abu sekam padi, minyak jelantah, metilen biru, asam lemak bebas, biodiesel

\begin{abstract}
Rice husk ash (ASP) is the waste of brick burning process that has potential as an adsorbent because it has a high silica content. This study aimed to determine the potential of rice husk ash as adsorbent in the process of biodiesel production from used cooking oil. Rice husk ash applied both on the purification of waste cooking oil and biodiesel. This research was conducted with several stages namely ASP characterization, purification of waste cooking oil, the manufacture of biodiesel through trans-esterification with $\mathrm{NaOH}$ as catalyst, purification of biodiesel with ASP 1, 3, 5\% and characterization of biodiesel. Rice husk ash had a specific area (methylene blue method) amounted to $119.59 \mathrm{~m}^{2} / \mathrm{g}$. Rice husk ash could reduce levels of free fatty acids in used cooking oil by $62.4 \%$. The trans-esterification process from used cooking oil produce biodiesel $96 \%$. The optimum ASP for purifying biodiesel is $3 \%$ with value of the acid number, total glycerol and ester value respectively 2.5 $\mathrm{mg} \mathrm{KOH} / \mathrm{g}, 0.37 \%$ and $98.37 \%$. The quality of biodiesel produced not meet the requirements of SNI.
\end{abstract}

Keywords : biodiesel, ester value, free fatty acid, methylene blue, rice husk ash, total glycerol, used cooking oil 


\section{PENDAHULUAN}

Perkembangan era globalisasi yang diikuti oleh pertumbuhan industri dan ekonomi yang pesat, serta peningkatan jumlah penduduk menyebabkan peningkatan jumlah konsumsi energi yang signifikan. Data dari Badan Pengkajian dan Penerapan Teknologi (BPPT) dalam Outlook Energi Indonesia 2016 menyatakan bahwa penyumbang angka konsumsi energi tertinggi adalah industri (48\%) dan transportasi (35\%) yang masih mengandalkan sumber-sumber energi tak terbarukan seperti batubara, gas, dan minyak bumi, sedangkan penggunaan bahan bakar non minyak atau biofuel dari tahun ke tahun semakin meningkat namun pada tahun 2014 baru mencapai angka $9 \%$. Oleh karena itu, saat ini banyak dilakukan penelitian terkait pengembangan energi alternatif untuk meningkatkan produksi dan konsumsi biofuel tersebut (Sugiyono, Aninditha, Wahid, dan Adiarso, 2016).

Salah satu bahan bakar alternatif yang banyak dikembangkan adalah biodiesel. Biodiesel merupakan bioenergi yang dibuat dari minyak nabati, melalui proses transesterifikasi, esterifikasi, atau proses esterifikasi-transesterifikasi. Salah satu bahan baku yang potensial untuk dikembangkan menjadi biodiesel adalah minyak jelantah yang merupakan yang merupakan limbah sisa penggorengan. Di Indonesia sendiri, pada tahun 2014 konsumsi minyak goreng mencapai 7,8 juta ton dan meningkat menjadi 8,5 juta ton pada tahun 2015 (indexmundi, 2016).

Minyak jelantah dapat diubah menjadi biodiesel dengan cara mereaksikannya dengan alkohol membentuk senyawa ester. Meski demikian, minyak jelantah tidak dapat langsung direaksikan karena memiliki kandungan asam lemak bebas. Kandungan asam lemak bebas (Free Fatty Acid atau FFA) bahan baku lebih dari 3\% pada reaksi transesterifikasi menggunakan katalis alkali menyebabkan terbentuknya sabun (Allah dan Alexandru, 2016) dan akan mengkonsumsi katalis (Gashaw dan Teshita, 2014). Oleh karena itu perlu dilakukan pemurnian terhadap minyak jelantah sebelum digunakan.

Salah satu metode pemurnian minyak jelantah adalah adsorbsi menggunakan abu sekam padi (ASP). Sekam padi merupakan limbah sisa penggilingan padi yang diperoleh antara $20-30 \%$ dari bobot gabah awal. Indonesia sendiri pada tahun 2015 memproduksi 75,40 juta ton gabah kering giling. Abu sekam padi merupakan hasil pembakaran sekam padi yang mengandung 87-97\% silika, bersifat ringan dan berpori (Kumar, Sangwan, Dhankhar, dan Bidra, 2013). Abu sekam padi ini jumlahnya melimpah dan mudah diperoleh terutama sebagai limbah pembakaran batu bata. Menurut Muntohar (2011), mineral utama dalam abu sekam padi sisa pembakaran batu bata adalah tridimit yang merupakan silika amorf.

Biodiesel yang dihasilkan dari reaksi transesterifikasi tidak dapat langsung digunakan, karena masih mengandung sisa reaksi dan pengotor lain yang dapat menimbulkan bahaya pada sistem pembakaran. Zat pengotor yang terkandung di dalam biodiesel kasar antara lain sabun, gliserol, asam lemak bebas, sisa alkohol, katalis, air dan sisa trigliserida yang tidak bereaksi. Kadar gliserol yang tinggi dalam biodiesel dapat menyebabkan deposit pada sistem injeksi dan memicu peningkatan emisi aldehid. Kandungan air dalam biodiesel dapat menyebabkan korosi pada mesin sedangkan sabun dan asam lemak bebas menyababkan kerusakan komponen tertentu pada mesin (Faccini et al., 2011). Metanol dapat menyebabkan densitas dan viskositas yang rendah pada biodiesel dan korosi pada logam Al dan Zn. Logam dari sisa katalis dan sabun dapat menyebabkan kerak pada injector dan penyumbatan filter (Berrios dan Skelton, 2008).

Oleh karena itu, biodiesel yang akan digunakan harus dimurnikan terlebih dahulu, agar memenuhi standar biodiesel. Terdapat dua metode umum untuk memurnikan biodiesel yaitu metode basah (wet washing) dan metode kering (dry washing). Metode basah menggunakan air adalah metode yang paling umum digunakan karena selain dapat melarutkan kontaminan, air juga tersedia dalam jumlah melimpah dan ekonimis. Namun, penggunaan air memiliki kelemahan yaitu menyebabkan pembentukan emulsi, asam lemak bebas dan sabun (Manique, Faccini, Onorevoli, Benvenutti, dan Caramao, 2012). 
Limbah cair yang dihasilkan dari pemurnian dengan metode basah juga menjadi permasalahan tersendiri bagi lingkungan (Faccini et al., 2011).

Pemurnian biodiesel dengan metode adsorbsi (dry washing) telah banyak diteliti sebagai alternatif dari metode basah karena prosesnya cepat dan tidak menghasilkan residu cairan. Adsorben berbasis silika adalah salah satu jenis adsorben yang telah diaplikasikan dalam pemurnian biodiesel. (Berrios \& Skelton, 2008) menggunakan Magnesol (magnesium silikat komersial) untuk pemurnian biodiesel yang menunjukkan penurunan kadar metanol dalam biodiesel dibandingkan resin penukar ion. Silika gel juga terbukti memiliki performa yang baik dalam pemurnian biodiesel dibanding metode basah menggunakan asam fosfat $5 \%$ dan air (Predojevic, 2008).

Penelitian ini akan mengkaji pemanfaatan ASP dari sisa pembakaran batu bata sebagai adosorben pada pembuatan biodiesel. Abu sekam padi yang memiliki kadar silika yang tinggi serta strukturnya yang bersifat amorf dengan luas permukaan yang cukup tinggi memungkinkan untuk digunakan sebagai adsorben baik dalam pemurnian bahan baku minyak jelantah maupun biodiesel. Proses pemurnian biodiesel menggunakan ASP ini diharapkan mampu meningkatkan kualitas biodiesel sehingga memenuhi standar SNI 7182:2015 tentang Biodiesel (BSN, 2015).

\section{METODE \\ Alat}

Alat yang dipakai dalam penelitian ini meliputi seperangkan alat gelas, magnetic stirrer, alat Gas Chromatography - Mass Spectrofotometer (GC-MS) QP-2010-SE, neraca analitik (Ohaus), alat Fourier Transform Infra Red (FTIR) Thermo Nicolet Avatar 360 dan alat Spektrofotometer UV Vis Thermo Genesys 20.

\section{Prosedur Penelitian}

Penelitian ini dilakukan dengan memodifikasi metode yang telah dilakukan oleh Manique et al. (2012) yang terdiri dari beberapa tahap yaitu preparasi dan karakterisasi ASP, pemurnian minyak jelantah, karakterisasi minyak jelantah, pembuatan biodiesel, pemurnian biodiesel dan karakterisasi biodiesel (Gambar 1).

\section{Karakterisasi ASP}

Abu sekam padi sisa pembakaran batu bata diayak dengan ayakan 150 mesh. Gugus fungsi ditentukan dengan menggunakan instrumentasi FTIR dan luas permukaan spesifik adsorben ASP ditentukan dengan metode adsorbsi metilen biru dengan cara sebagai berikut: sebanyak $0,1 \mathrm{~g}$ ASP ditambahkan dalam larutan metilen biru $50 \mathrm{~mL} 100 \mathrm{mg} / \mathrm{L}$ kemudian dishaker dengan variasi waktu kontak 10 , 20, 30, 40, 50, 60, 70 dan 80 menit. Larutan kemudian disaring dengan kertas saring Whatman 42. Filtrat diencerkan 25 kali dan absorbansi diukur menggunakan spektrofotometri UV-Visible pada panjang gelombang $664 \mathrm{~nm}$.

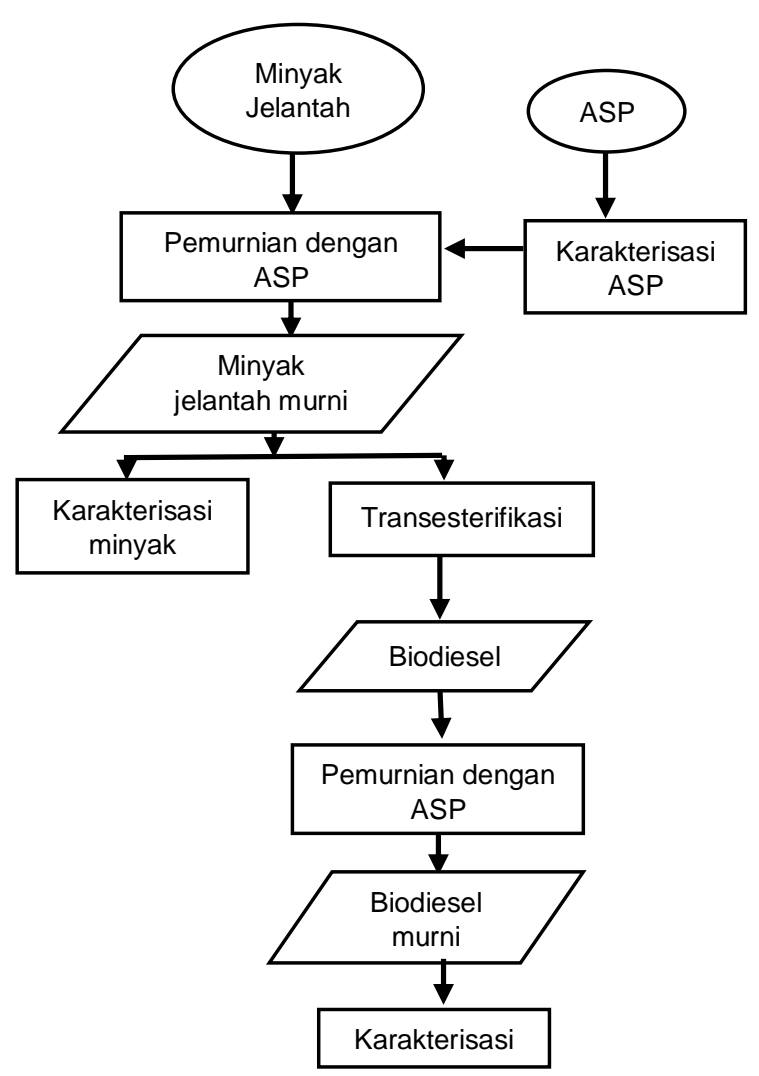

Gambar 1. Skema prosedur penelitian (Manique et al., 2012)

\section{Pemurnian Minyak Jelantah}

Minyak Jelantah ditimbang sebanyak $100 \mathrm{~g}$ dan ditambah $10 \mathrm{~g}$ ASP dari sisa pembakaran batu bata. Campuran diaduk dengan magnetic stirrer selama 80 menit. 
Campuran kemudian disaring dan diperoleh filtrat.

\section{Penentuan Asam Lemak Bebas (Free Fatty Acid) Minyak jelantah}

Kadar asam lemak bebas (FFA) minyak jelantah sebelum dan sesudah pemurnian ditentukan dengan metode SNI 3741:2013 tentang Minyak Goreng (BSN, 2013). Sebanyak 10-50 g minyak jelantah dimasukkan dalam erlenmeyer dan ditambah $50 \mathrm{~mL}$ etanol netral hangat dan beberapa tetes indikator feloftalein. Larutan kemudian dititrasi dengan $\mathrm{KOH} 0,1 \mathrm{~N}$ sampai terbentuk warna merah muda. Bilangan asam dan FFA ditentukan dengan rumus berikut:

bilangan asam $\left(\frac{m g K O H}{g}\right)=\frac{56,1 \times V \times N}{W}$

$F F A(\%)=\frac{V \times N \times 256,42}{w \times 1000} \times 100 \%$

dengan

$\mathrm{V} \quad$ : volume titrasi $(\mathrm{mL})$

$\mathrm{N} \quad$ : normalitas $\mathrm{KOH}(\mathrm{N})$

w : masa minyak $(\mathrm{g})$

$56,1 \quad$ : $\mathrm{MrOH}(\mathrm{g} / \mathrm{mol})$

256,42: Mr asam palmitat $(\mathrm{g} / \mathrm{mol})$

\section{Pembuatan Biodiesel}

Pembuatan biodiesel dilakukan menggunakan rasio molar minyak : metanol (1:6) (Manique et al., 2012) dengan asumsi berat molekul minyak jelantah adalah 541,7 $\mathrm{g} / \mathrm{mol}$. Sebanyak 50 gram minyak jelantah direaksikan dengan larutan katalis-metanol, (0,5 gram $\mathrm{NaOH}$ dilarutkan dalam 17,72 gram metanol). Minyak direfluks sampai suhu $50-55^{\circ} \mathrm{C}$, kemudian larutan $\mathrm{NaOH}-$ metanol dimasukkan, dan dilanjutkan pemanasan sampai 1 jam. Hasil refluks dimasukkan kedalam corong pisah dan diamkan semalam sampai memisah. Lapisan gliserol di bawah dibuang dan lapisan metil ester dibagian atas diambil dan dianalisis hasil dengan Kromatografi GasSpektrometri Massa (GC-MS).

\section{Pemurnian Biodisel}

Sebanyak 50 gram biodisel ditambahkan ASP sebanyak 1\%, 3\% dan $5 \%$ (dari berat biodiesel). Campuran dipanaskan pada suhu $65^{\circ} \mathrm{C}$ dan aduk selama 30 menit. Campuran disaring dengan kertas saring Wathman 42. Hasil adsorbsi dianalisis dengan GC-MS dan ditentukan angka asam, gliserol total dan angka penyabunan.

\section{Penentuan angka asam}

Penentuan angka asam dilakukan berdasarkan metode FBI-A01-03 (FBI, 2006). Sebanyak 19-21 g biodiesel dimasukkan dalam erlenmeyer dan ditambahkan $100 \mathrm{~mL}$ campuran pelarut yaitu dietil eter : etanol 95\% (1:1). Larutan ditambah beberapa tetes indikator fenolftalein dan dititrasi dengan $\mathrm{KOH}$ alkoholis $0,1 \mathrm{~N}$ sampai berwarna merah muda. Angka asam biodiesel dihitung dengan menggunakan rumus (1).

\section{Penentuan gliserol total}

Penentuan gliserol total dilakukan berdasarkan metode $\mathrm{FBI}-\mathrm{A02}$-03 (FBI, 2006a). Sebanyak $10 \mathrm{~g}$ biodiesel dimasukkan dalam labu alas bulat dan ditambah $100 \mathrm{~mL} \mathrm{KOH}$ alkoholis (dibuat dengan melarutkan $4 \mathrm{~g} \mathrm{KOH}$ dalam $100 \mathrm{~mL}$ etanol 95\%). Larutan direfluks perlahan selama 30 menit. Hasil refluks didinginkan sampai suhu kamar.

Sebanyak $91 \mathrm{~mL}$ kloroform dimasukkan dalam labu ukur $1 \mathrm{~L}$ kemudian ditambah $25 \mathrm{~mL}$ asam asetat glasial dan hasil refluks biodiesel secara kuantitatif dengan menggunakan $500 \mathrm{~mL}$ akuades sebagai pembilas. Kocok labu ukur kuatkuat selama 30-60 detik. Akuades ditambahkan sampai tanda batas dan dihomogenkan. Larutan didiamkan sampai lapisan kloroform dan air terpisah sempurna.

Sebanyak $6 \mathrm{~mL}$ larutan asam periodat dimasukkan dalam erlenmeyer kemudian ditambahkan $100 \mathrm{~mL}$ lapisan air (lapisan atas) yang telah diperoleh sebelumnya. Larutan dikocok dan didiamkan selama 30 menit dalam keadaan tertutup. Larutan kemudian ditambah $3 \mathrm{~mL}$ larutan $\mathrm{KI}$ dan dikocok serta disimpan dalam ruang gelap selama 1 menit dan dititrasi dengan larutan natrium tiosulfat $0,1 \mathrm{~N}$ sampai mendekati titik akhir titrasi. Larutan ditambahn indikator amilum dan titrasi dilanjutkan sampai warna biru hilang. Titrasi dilakukan juga terhadap balngko dengan mengganti asam periodat 
dengan akuades $50 \mathrm{~mL}$. Kadar gliserol total ditentukan dengan rumus:

$G_{t t l(\%)}=\frac{2,302 x(B-C) x N}{w}$

$w=\frac{\text { berat sampel } x \text { volume sampel }}{900}$

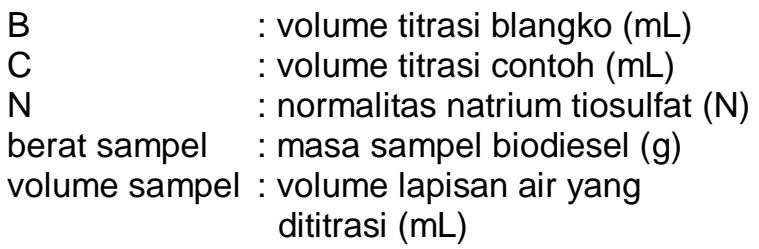

\section{Penentuan angka penyabunan}

Penentuan angka penyabunan dilakukan berdasarkan metode FBI-A03-03 (FBI, 2006b). Sebanyak 4-5 g biodiesel dimasukkan dalam labu alas bulat kemudian ditambah $50 \mathrm{~mL} \mathrm{KOH}$ alkoholis. Larutan $\mathrm{KOH}$ alkoholis dibuat dengan cara merefluks $10 \mathrm{~g} \mathrm{KOH}$ dengan 1,2 L etanol 95\% dan destilat ditampung sebanyak $1 \mathrm{~L}$. Destilat ditambah $40 \mathrm{~g} \mathrm{KOH}$ dan didiamkan selama 5 hari kemudian larutan $\mathrm{KOH}$ alkoholis didekantasi untuk memisahkan pengotor.

Campuran biodiesel dan $\mathrm{KOH}$ alkoholis kemudian direfluks sampai mendidih kurang lebih 1 jam atau sampai warna larutan jernih dan homogen. Larutan kemudian didinginkan dan dipindahkan secara kuantitatif ke dalam erlenmeyer. Larutan kemudian dititrasi dengan $\mathrm{HCl} 0,5 \mathrm{~N}$ menggunakan indikator fenolftalein sampai warna merah muda hilang. Prosedur ini dilakukan pula untuk blangko dengan mengganti sampel biodiesel dengan akuades. Angka penyabunan ditentukan dengan menggunakan rumus:

bil.penyabunan $\left(m g \frac{K O H}{g}\right)=\frac{56,1 \times(B-C) \times N}{m}$

dengan:

$\begin{array}{ll}56,1 & \text { : Mr } \mathrm{KOH} \\ \mathrm{B} & \text { : volume titrasi blanko }(\mathrm{mL}) \\ \mathrm{C} & \text { : volume titrasi sampel }(\mathrm{mL}) \\ \mathrm{N} & \text { : normalitas } \mathrm{HCl} \\ \mathrm{m} & \text { : masa sampel biodiesel }(\mathrm{g})\end{array}$

HASIL DAN PEMBAHASAN

Karakterisasi Abu Sekam Padi

Karakteristik dari ASP dilakukan dengan menggunakan FTIR untuk mengetahui gugus fungsi sedangkan luas permukaan spesifik diuji dengan menggunakan metode metilen biru. Gambar 2.menunjukkan spectra FTIR dari ASP. Pita serapan pada $1096 \mathrm{~cm}^{-1}$ merupakan vibrasi stretchingdari Si-O, serapan pada $791 \mathrm{~cm}^{-1}$ menunjukkan struktur cincin dari $\mathrm{SiO}_{4}$ tetrahedral, sedangkan serapan pada 470 $\mathrm{cm}^{-1}$ terkait dengan deformasi Si-O-Si. Serapan pada $3443 \mathrm{~cm}^{-1}$ merupakan vibrasi stretching dari $\mathrm{O}-\mathrm{H}$ silanol (Manique et al., 2012)

Pita serapan pada 1637 merujuk pada vibrasi bending $\mathrm{H}-\mathrm{O}-\mathrm{H}$ dari air yang terserap (Saikia \& Parthasarathy, 2010), sedangkan serapan pada $2361 \mathrm{~cm}^{-1}$ menunjukkan adanya gugus karbonat yang terbentuk akibat reaksi dengan $\mathrm{CO}_{2}$ udara selama pembakaran ASP.

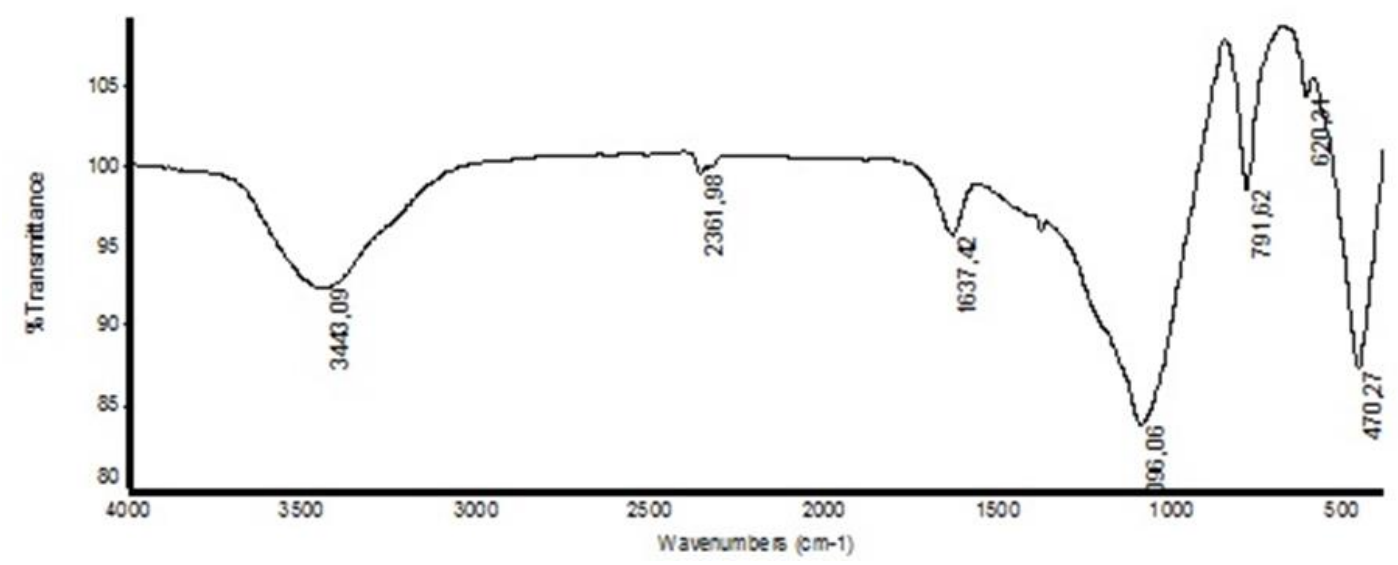

Gambar 2. Spektra FTIR ASP 
Penentuan luas area spesifik dilakukan dengan metode adsorbsi metilen biru dengan perlakuan variasi waktu kontak. Metilen biru dipilih sebagai adsorbat karena telah diketahui bahwa metilen biru dapat teradsorbsi kuat pada berbagai material padatan (Itodo, Itodo, \& Gafar, 2010). Sisa metilen biru yang tidak teradsorbsi ditentukan dengan spektrofotometer UV Vis pada panjang gelombang $664 \mathrm{~nm}$. Jumlah metilen biru yang terserap dan luas area spesifik ASP ditentukan dengan persamaan (6) dan persamaan (7) (Dwitama, Nazib, dan Sitepu, 2016).

$$
\begin{aligned}
& X_{m}=\frac{\left(C_{0}-C_{t}\right) V}{W} \\
& S=\frac{X_{m} N a}{M r 1000}
\end{aligned}
$$

Dengan

$\mathrm{X}_{\mathrm{m}} \quad$ : jumlah metilen biru yang terserap

$$
\begin{array}{ll} 
& (\mathrm{mg} / \mathrm{g}) \\
\mathrm{C}_{0} & \text { : konsentrasi metilen biru awal }(\mathrm{mg} / \mathrm{L}) \\
\mathrm{C}_{\mathrm{t}} & \text { : konsentrasi metilen biru akhir }(\mathrm{mg} / \mathrm{L}) \\
\mathrm{V} & : \text { volume larutan metilen biru }(\mathrm{L}) \\
\mathrm{W} & : \text { masa adsorben }(\mathrm{g}) \\
\mathrm{S} & : \text { luas area spesifik }\left(\mathrm{m}^{2} / \mathrm{g}\right) \\
\mathrm{N} & \text { : bilangan Avogadro } 6.022 \times 10^{23} / \mathrm{mol} \\
\mathrm{a} & \text { : luas penutupan oleh } 1 \mathrm{molekul} \\
& \text { metilen biru }\left(197 \times 10^{-20} \mathrm{~m}^{2}\right)
\end{array}
$$

Tabel 1 dan Gambar 3 menunjukkan bahwa semakin lama waktu kontak, jumlah metilen biru yang teradsorbsi juga semakin meningkat dan mencapai optimum pada waktu kontak 60 menit. Waktu optimum ini digunakan untuk menentukan luas permukaan spesifik dari ASP yaitu 119,593 $\mathrm{m}^{2} / \mathrm{g}$. Adanya gugus silanol dalam ASP diprediksi berperan dalam kemampuan adsorpsi yang tinggi terhadap metilen biru (Alzaydien, 2009).

Tabel 1. Hasil adsorbsi metilen biru dengan perlakuan waktu

\begin{tabular}{ccccc}
\hline Waktu (menit) & $\mathrm{C}_{\mathrm{t}}$ & $\mathrm{C}_{\mathrm{t}}-\mathrm{C}_{0}$ & $\mathrm{X}_{\mathrm{m}}(\mathrm{mg} / \mathrm{g})$ & $\mathrm{S}\left(\mathrm{m}^{2} / \mathrm{g}\right)$ \\
\hline 10 & 59.065 & 40.935 & 20.468 & 75.761 \\
20 & 58.041 & 41.959 & 20.980 & 77.656 \\
30 & 49.976 & 50.024 & 25.012 & 92.583 \\
40 & 48.823 & 51.177 & 25.588 & 94.715 \\
50 & 42.039 & 57.961 & 28.981 & 107.272 \\
60 & 35.382 & 64.618 & 32.309 & 119.593 \\
70 & 42.423 & 57.577 & 28.789 & 106.562 \\
80 & 45.623 & 54.377 & 27.188 & 100.638 \\
\hline
\end{tabular}

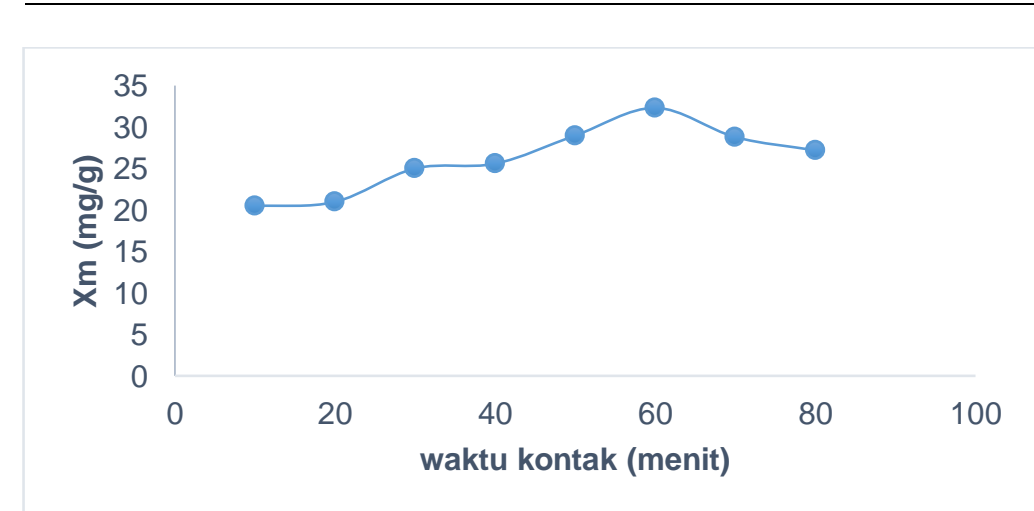

Gambar 3. Pengaruh waktu kontak terhadap adsorbsi metilen biru pada ASP 


\section{Pemurnian Minyak Jelantah}

Pemurnian minyak jelantah sebagai bahan baku biodiesel dilakukan khususnya untuk mengurangi asam lemak bebas yang akan menyebabkan produk samping berupa sabun dalam reaksi transesterifikasi. Kadar FFA dalam minyak jelantah ditentukan sebagai asam palmitat dalam minyak jelantah Tabel 2. Tabel 2 menunjukkan bahwa ASP mampu menurunkan kadar FFA dalam minyak jelantah sebesar 62,4 \% sehingga kadar FFA dalam minyak jelantah menjadi < $3 \%$. Kadar FFA dalam bahan baku pembuatan biodiesel yang lebih dari 3\% akan menyebabkan terbentuknya sabun (Allah dan Alexandru, 2016) dan meningkatkan konsumsi katalis (Gashaw dan Teshita, 2014).

Tabel 2. Karakterisasi minyak jelantah

\begin{tabular}{lcc}
\hline \multicolumn{1}{c}{ Sampel } & $\begin{array}{c}\text { Bilangan Asam } \\
(\mathrm{mg} \mathrm{KOH} / \mathrm{g})\end{array}$ & FFA (\%) \\
\hline $\begin{array}{l}\text { Sebelum } \\
\text { pemurnian }\end{array}$ & 8,52 & 3,94 \\
$\begin{array}{l}\text { Setelah } \\
\text { pemurnian }\end{array}$ & 3,25 & 1,48 \\
\hline
\end{tabular}

\section{Pembuatan Biodiesel}

Pembuatan biodiesel dilakukan melalui reaksi transesterifikasi minyak jelantah hasil adsorbsi dengan katalis $\mathrm{NaOH}$ $1 \%$ dan rasio molar minyak:metanol (1:6). Reaksi dilakukan dengan cara refluks pada suhu $50-55^{\circ} \mathrm{C}$ selama 1 jam. Hasil refluks didiamkan semalam sehingga

terbentuk dua lapisan. Lapisan atas diambil sebagai biodiesel dan komposisinya diuji dengan GC-MS. Hasil GC-MS biodiesel sebelum pemurnian ditunjukkan pada Gambar 4.

Gambar 4. menunjukkan adanya dua puncak dominan yaitu pada waktu retensi 17,416 dan 19,240 yang berturut-turut merupakan senyawa pentadecanoic acid, 14-methyl-, methyl ester dan methyl oleate dengan luas area masing-masing adalah $43,57 \%$ dan $52,43 \%$. Kedua senyawa tersebut merupakan senyawa metil ester atau biodiesel. Kromatogram tersebut juga menunjukkan beberapa senyawa lain dengan kadar yang sangat kecil dibanding senyawa metil ester.

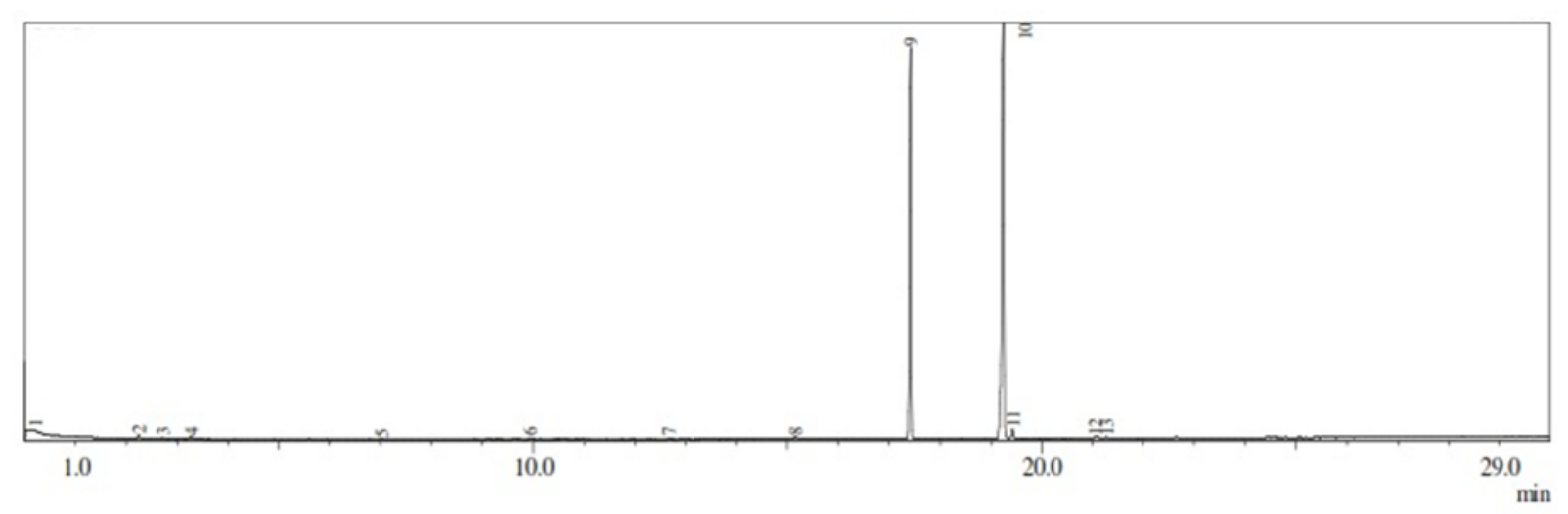

Gambar 4. Kromatogram GC sebelum pemurnian

\section{Pemurnian Biodiesel}

Biodiesel yang dihasilkan belum dilakukan pemurnian sehingga dimungkinkan masih banyak pengotor seperti FFA, gliserol dan sabun. Oleh karena itu biodiesel harus dimurnikan yaitu dengan metode dry washing atau adsorbsi. Adsorben yang digunakan adalah ASP yang juga digunakan dalam pemurnian minyak jelantah sehingga diharapkan adsorben ASP memiliki multi fungsi yang akan meningkatkan nilai ekonomis dari ASP.

Adsorbsi biodiesel dilakukan dengan variasi masa ASP yaitu 1, 3 dan $5 \%$ dari masa biodiesel dengan menggunakan stirrer selama 30 menit pada suhu $60^{\circ} \mathrm{C}$. Biodiesel yang telah dimurnikan kemudian dikarakterisasi dengan parameter bilangan asam, bilangan penyabunan, gliserol total dan bilangan ester. Nilai bilangan ester dihitung berdasarkan nilai dari bilangan 
asam, bilangan penyabunan dan gliserol total dengan persamaan 8 . Nilai dari masingmasing parameter tersebut ditunjukkan pada Tabel 3.

kadar ester $(\%)=\frac{100\left(A_{S}-A_{a}-4,57 G_{t t l}\right.}{A_{s}}$

(8) dengan
$\mathrm{A}_{\mathrm{s}} \quad$ : angka penyabunan
$A_{a} \quad$ : angka asam
$\mathrm{G}_{\mathrm{ttl}} \quad$; kadar gliserol total

Tabel 3. Karakterisasi biodiesel hasil pemurnian dengan ASP

\begin{tabular}{lcccc}
\hline Sampel & $\begin{array}{c}\text { Bilangan } \\
\text { Asam } \\
(\mathrm{mg} \mathrm{KOH} / \mathrm{g})\end{array}$ & $\begin{array}{c}\text { Bilangan } \\
\text { Penyabunan } \\
(\mathrm{mg} \mathrm{KOH} / \mathrm{g})\end{array}$ & $\begin{array}{c}\text { Gliserol } \\
\text { Total } \\
(\%)\end{array}$ & $\begin{array}{c}\text { Bilangan } \\
\text { Ester } \\
(\%)\end{array}$ \\
\hline Biodiesel sebelum adsorbsi & 3.27 & $*$ & 0.42 & $*$ \\
Biodiesel setelah adsorbsi ASP 1\% & 2.60 & 96.87 & 0.37 & 95.58 \\
Biodiesel setelah adsorbsi ASP 3\% & 2.50 & 256.61 & 0.37 & 98.37 \\
Biodiesel setelah adsorbsi ASP 5\% & 2.40 & 182.34 & 0.40 & 97.69 \\
\hline
\end{tabular}

*tidak dilakukan

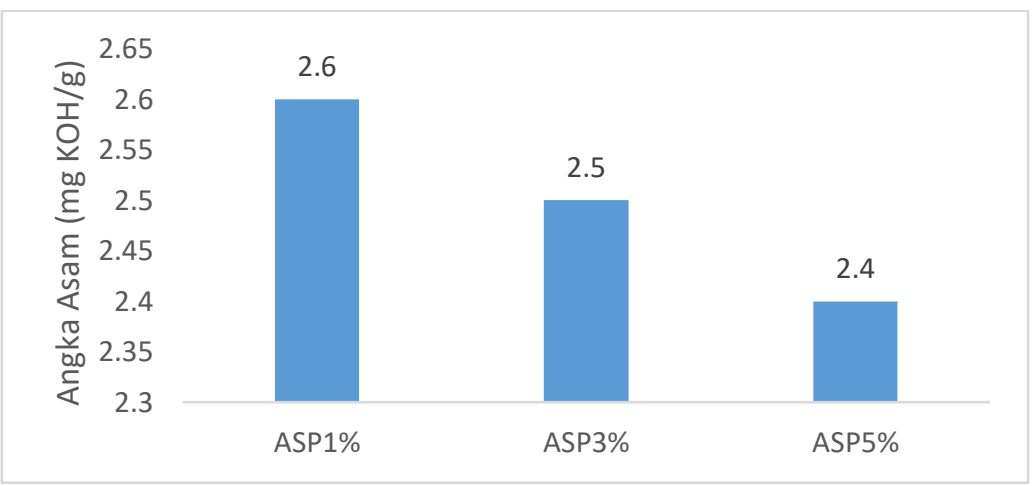

Gambar 5. Pengaruh masa adsorben terhadap angka asam biodiesel

Tabel 3 dan Gambar 5 menunjukkan bahwa proses adsorbsi dengan ASP mampu menurunkan nilai angka asam mencapai $26,6 \%$. Semakin banyak masa adsorben yang digunakan, nilai bilangan asamnya juga semakin turun yaitu mencapai 2,4 mg $\mathrm{KOH} / \mathrm{g}$ pada pemakaian ASP $5 \%$. Namun nilai ini masih jauh dari yang dipersyaratkan oleh SNI 7182:2015 (BSN, 2015) yaitu nilai bilangan asam maksimal adalah $0,5 \mathrm{mg}$ $\mathrm{KOH} / \mathrm{g}$. Hal ini dapat disebabkan karena bilangan asam minyak jelantah yang digunakan masih tinggi yaitu $3,25 \mathrm{mg}$ $\mathrm{KOH} / \mathrm{g}$. Angka asam yang tinggi menunjukkan bahwa biodiesel masih mengandung asam lemak bebas (FFA) sehingga biodiesel bersifat korosif dan dapat menimbulkan jelaga atau kerak di injektor mesin diesel (Prihandana, 2006). Menurut He dan Gerpen (2012) biodiesel yang baru saja dihasilkan dari reaksi transesterifikasi memiliki angka asam yang rendah karena katalis alkali biasanya akan mengkonversi asam lemak bebas menjadi sabun. Angka asam yang tinggi dalam biodiesel menunjukkan bahwa katalis $\mathrm{NaOH} 1 \%$ belum mampu menetralkan asam lemak bebas yang terkandung dalam minyak jelantah (Nurdiansyah dan Redha, 2011).

Tabel 3 juga menunjukkan bahwa proses pemurnian dengan ASP dapat menurunkan kadar gliserol total yang merupakan produk samping dari reaksi transesterifikasi. Gliserol total ditentukan dengan prinsip asam periodat berlebih bereaksi dengan gliserol dan sisa $\mathrm{IO}_{4}^{-}$ direaksikan dengan KI. lodium yang dibebaskan kemudian dititrasi dengan natrium tiosulfat dengan indikator amilum hingga terjadi perubahan warna dari biru menjadi tidak berwarna (Pisarello, Costa, Veizaga, dan Querini, 2010).

$$
\begin{aligned}
& \mathrm{C}_{3} \mathrm{H}_{8} \mathrm{O}_{3}+2 \mathrm{IO}_{4}^{-} \rightarrow 2 \mathrm{HCHO}+\mathrm{HCOOH}+2 \mathrm{IO}_{3}{ }^{-}+\mathrm{H}_{2} \mathrm{O} \\
& \mathrm{IO}_{4}{ }^{-}+2 \mathrm{I}^{-}+\mathrm{H}_{2} \mathrm{O} \rightarrow \mathrm{IO}_{3}{ }^{-}+\mathrm{I}_{2}+2 \mathrm{OH}^{-}
\end{aligned}
$$




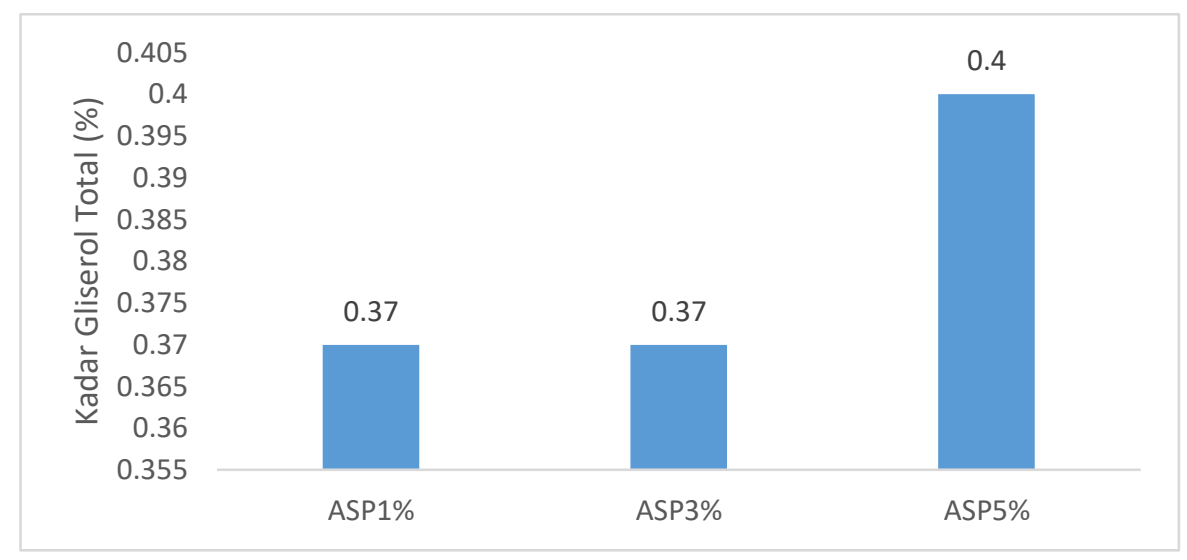

Gambar 6. Pengaruh masa ASP terhadap kadar gliserol total biodiesel

Nilai gliserol total terendah dalam biodiesel hasil adsorbsi dengan ASP adalah $0,37 \%$ yang masih di atas batas maksimal yang dipersyaratkan oleh SNI yaitu $0,24 \%$. Gambar 6. menunjukkan bahwa semakin banyak masa adsorben tidak berpengaruh secara signifikan terhadap penurunan kadar gliserol total biodiesel bahkan justru semakin meningkat. Hal ini dapat disebabkan senyawa metil ester ikut terserap dalam pori biodiesel. Menurut Manique et al. (2012) permukaan ASP didominasi oleh pori berukuran mesopori bahkan makropori sehingga memungkinkan penyerapan senyawa metil ester. Keberadaan gliserol dalam biodiesel dapat membahayakan mesin diesel terutama akibat adanya gugus $\mathrm{OH}$ yang bersifat reaktif terhadap logam bukan besi dan campuran krom (Prihandana, Hendroko, dan Nuramin, 2006).

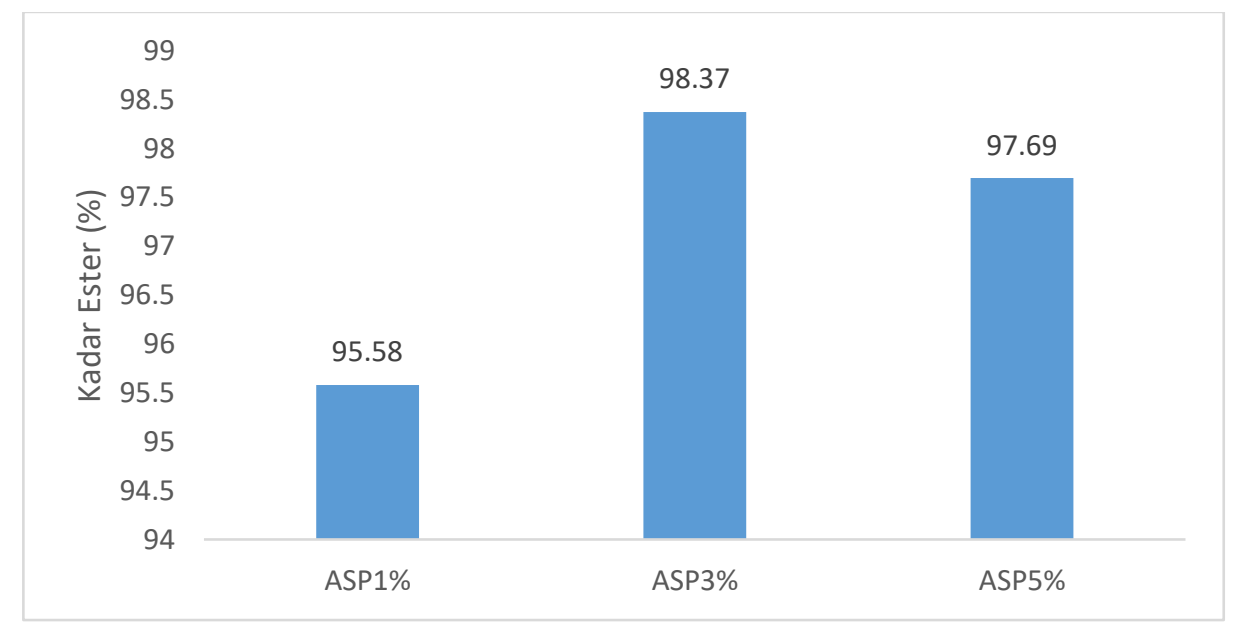

Gambar 7. Pengaruh masa ASP terhadap kadar ester biodiesel

Parameter bilangan penyabunan tidak dipersyaratkan dalam SNI namun parameter ini akan mempengaruhi nilai bilangan ester. Nilai bilangan penyabunan tertinggi diperoleh pada pemurnian dengan menggunakan ASP $3 \%$ yang juga menghasilkan nilai bilangan ester tertinggi yaitu $98,37 \%$ (Gambar 7 ). Nilai bilangan ester ini telah memenuhi persyaraan minimal kadar metil ester yaitu $96,5 \%$. Nilai bilangan ester yang menurun pada pemakaian ASP $5 \%$ kemungkinan 
disebabkan senyawa metil ester ikut terserap dalam pori-pori ASP.

Dari keempat parameter tersebut dapat disimpulkan bahwa adsorben ASP yang optimum untuk pemurnian biodiesel adalah ASP 3\%. Namun kualitas biodiesel ini masih belum memenuhi persyaratan standar biodiesel. Menurut Felizardo et al., (2006) kemurnian biodiesel dipengaruhi oleh kualitas minyak jelantah yang digunakan, yang menunjukkan bahwa semakin rendah bilangan asam minyak jelantah maka semakin tinggi kemurnian biodiesel yang dihasilkan.

\section{SIMPULAN \\ Kesimpulan}

Dari hasil penelitian ini dapat disimpulkan bahwa abu sekam padi sisa pembakaran batu bata dapat digunakan untuk memurnikan minyak jelantah melalui penurunan kadar asam lemak bebas sebesar $62,4 \%$ yang kemudian digunakan sebagai bahan baku pembuatan biodiesel. Biodiesel yang dihasilkan menunjukkan dua senyawa utama yaitupentadecanoic acid, 14-methyl-, methyl ester dan methyl oleatedengan total luas area adalah $96 \%$.

Pemurnian biodiesel dengan ASP dapat menurunkan nilai bilangan asam dan gliserol total serta meningkatkan nilai bilangan ester dengan masa ASP optimum adalah 3\% dari masa biodiesel. Namun, kualitas biodiesel yang dihasilkan masih belum memenuhi persyaratan SNI7182:2015.

\section{Saran}

Kualitas biodiesel dapat ditingkatkan melalui penurunan kadar asam lemak bebas dalam minyak jelantah dengan proses esterifiksi. Sedangkan proses pemurnian biodiesel dapat ditingkatkan dengan melakukan aktivasi terhadap abu sekam padi.

\section{DAFTAR PUSTKA}

Allah, F. U. M., dan Alexandru, G. (2016). Waste cooking oil as source for renewable fuel in Romania. lasi.

Alzaydien, S. A. (2009). Adsorption of Methylene Blue from Aqueous
Solution onto a Low-Cost Natural Jordanian Tripoli, 6(6), 1047-1058.

Berrios, M., dan Skelton, R. L. (2008). Comparison of purification methods for biodiesel, 144, 459-465.

BSN. (2013). SNI 3741: 2013 tentang Minyak Goreng. Badan Standarisasi Nasional.

BSN. (2015). SNI 7182: 2015 tentang Biodiesel. Badan Standarisasi Nasional.

Faccini, C. S., Cunha, M. E., Moraes, M. S. A., Krause, L. C., Manique, M. C., Rodrigues, M. R. A., ... Caramão, E. B. (2011). Dry Washing in Biodiesel Purification: a Comparative Study of Adsorbents, 22(3), 558-563.

FBI. (2006a). FBI-A02-03 tentang Metode

Analisis Standar untuk Kadar

Gliserol Total, Bebas dan Terikat di Dalam Biodiesel Ester Alkil : Metode lodometri-Periodat. Forum Biodiesel Indonesia.

FBI. (2006b). FBI-A03-03 tentang Metode Analisis Standar untuk Angka Penyabunan dan Kadar Ester Biodiesel Ester Alkil. Forum Biodiesel Indonesia.

Felizardo, P., Correia, M. J. N., Raposo, I., Mendes, J. F., Berkemeier, R., dan Bordado, J. M. (2006). Production of biodiesel from waste frying oils, 26, 487-494.

Gashaw, A., dan Teshita, A. (2014). Production of biodiesel from waste cooking oil and factors affecting its formation: A review, 3(5), 92-98.

indexmundi. (2016). Indonesia Palm Oil Domestic Comsumption per Year. Retrieved from http://www.indexmundi.com/agricult ure/?country=id\&commodity=palmoil\&graph=domestic-consumption

Itodo, A. U., Itodo, H. U., dan Gafar, M. K. (2010). Estimation of Specific Surface Area using Langmuir Isotherm Method, 14(4), 141-145.

Kumar, S., Sangwan, P., Dhankhar, R. M. V., dan Bidra, S. (2013). Utilisation of Rice Husk and Their Ash, 1(5), 126129.

Manique, M. C., Faccini, C. S., Onorevoli, B., Benvenutti, E. V., dan Caramao, E. B. (2012). Rice husk ash as an 
adsorbent for purifying biodiesel from waste frying oil, 92(2012), 56-61.

Muntohar, A. S. (2011). Karaketeristik Kuat Geser Tanah Pasir dengan Campuran Kapur dan Abu Sekam Padi. Presented at the Pertemuan IImiah Tahunan XIV HATTI, Yogyakarta.

Nurdiansyah, dan Redha, A. (2011). Efek Lama Maserasi Bubuk Kopra Terhadap Rendemen, Densitas, dan Bilangan Asam Biodiesel yang Dihasilkan dengan Metode Transesterifikasi In Situ, 10(2), 218224.

Pisarello, M. L., Costa, B. O. D., Veizaga, N. S., dan Querini, C. A. (2010). Volumetric Method for Free and Total Glycerin Determination in Biodiesel, 49, 8935-8941.

Predojevic, Z. J. (2008). The production of biodiesel from waste frying oils: A comparison of different purification steps, 87, 3522-3528.

Prihandana, R., Hendroko, R., dan Nuramin, M. (2006). Menghasilkan Biodiesel Murah. Jakarta: Agromedia Pustaka.

Saikia, B. J., dan Parthasarathy, G. (2010). Fourier Transform Infrared Spectroscopic Characterization of Kaolinite from Assam and Meghalaya, Northeastern India, 1, 206-210.

Sugiyono, A., Aninditha, Wahid, L. M. A., dan Adiarso. (2016). Outlook Energi Indonesia 2016: Pengembangan Energi untuk Mendukung Industri Hijau. Jakarta: Pusat Teknologi Sumber Daya Energi dan Industri Kimia BPPT. 